\title{
ANALYSIS OF HARMFUL INGREDIENTS IN STUDENT SNACKS AT LUBUK PAKAM, DELI SERDANG DISTRICT, INDONESIA
}

\author{
O. Martony ${ }^{1}$, J. Silalahi ${ }^{2}$, Z. Lubis ${ }^{1}$, H. Santosa ${ }^{1}$ and R. Siburian ${ }^{3, *}$ \\ ${ }^{1}$ Department of Public Health, Universitas Sumatera Utara, Medan-20155, Indonesia \\ ${ }^{2}$ Department of Pharmacy, Universitas Sumatera Utara, Medan-20155, Indonesia \\ ${ }^{3}$ Department of Chemistry, Universitas Sumatera Utara, Medan-20155, Indonesia \\ *E-mail: riksonsiburian@usu.ac.id
}

\begin{abstract}
The inclusion of harmful ingredients into student snacks in Indonesia has been increasing by snack producers, which are generally small or household industries, and which should demand more attention from producers, the government, and consumers. This research attempted to identify harmful ingredients (formalin, sodium tetra borate, and rhodamine) in student snacks at Lubuk Pakam, and was conducted at Food Chemistry Laboratory, Nutrition Department Medical Polytechnic of Medan in September 2015. Representative samples were obtained from student snacks traders from 24 schools at Lubuk Pakam, and were analyzed by Ezzy Test kit for formalin, sodium tetra borate, and Rhodamine B. The results showed that the snacks positively contained formalin in $25 \%$ of the samples (6 of 24), sodium tetra borate $25 \%$ (6 of 24) of the samples and Rhodamine Bare $38.88 \%$ ( 7 of 18 samples). It can be concluded that there is the continued utilization of harmful ingredients in student snacks inLubuk Pakam.
\end{abstract}

Keywords: Harmful ingredients, Snacks, Harmful, Lubuk Pakam, Primary School Students.

(C) RASĀYAN. All rights reserved

\section{INTRODUCTION}

Food safety problems have become one of world attention due to it can affect many aspects, especially children. Children at student age, can be the biggest consumers of snacks, and thus often get poisoned from contaminated or adulterated snacks. Research from BPOM (Board of Medicine and Food Supervisor) indicates that $99 \%$ of students get their meals in the school to fulfill their need for nutrients, especially energy. Of all food samples checked, 40-45\% contained harmful chemical ingredients like formalin, sodium tetra borate, and food coloring substances such as Rhodamine B and methanyl yellow. Those problems indicate a lack of knowledge, concern, or awareness by student snack producers, traders, and consumers of the importance of food safety. ${ }^{1}$

Snacks containing formalin, sodium tetra borate, and Rhodamine B certainly do not directly cause aside effect over the short term. However, several researchers have shown that consuming formalin, sodium tetra borate, and Rhodamine B continuously can cause accumulative symptoms in the body, such as kidney and liver infection, cancer,a decrease of intelligence, and degenerative diseases ${ }^{2,3.4}$ Usually, formaldehyde, borax, and Rhodamine B are added in many products of food, especially in a snack. The formaldehyde is used in food as a preservative in order to extend the usage time. Borax always is used in food to enhance food be chewy. Therefore, the raw material may be decreased and the product will be seen more beautiful and interesting. Rhodamine B is used to increase the intensity of red color. Where it is needed to attract the consumer to purchase the food product. When formalin enters the human body, it can damage the digestive system, kidney failure, and is mutagenic and carcinogenic, which can cause the growth of cancer cells and genetic damage to the body. ${ }^{5-7,17-19}$ Sodium tetra borate can influence lymphocyte proliferation and cause cytotoxicity in immune cells (lymphocytes). ${ }^{8,9,16}$ Rhodamine B can damage the kidney, causing constriction of Bowman chamber at the glomerulus, hypertrophy, necrosis, and 
RASĀYAN J. Chem.

Vol. 10 | No. 4 |1505-1510| October - December

tubular cirrhosis ${ }^{4}$. According to Rule of Minister of Health Num. 722/Menkes/per/IX/88, formalin, sodium tetra borate, and Rhodamine B are forbidden to use in food.

However, it has been found that $16 \%$ of 216 snack samples analyzed contained formalin, $9.1 \%$ of $81 \%$ of the samples contained sodium tetra borate, and $2.3 \%$ of 781 samples positively contain Rhodamine B in 18 provinces in Indonesia. ${ }^{10}$

It was found that $50 \%$ of lontong (traditional rice cakes) positively contained sodium tetra borate in samples from North Medan, ${ }^{11}$ and 3 of 28 analyzed snack samples contained Rhodamine B at South Labuhan Batu, North Sumatra. ${ }^{12}$

Snacks are one of the household industry products that should be guaranteed as safe, considering snacks have an important role in providing energy and nutrition for school-age children. Snacks consumption needs to get more due to the high intensity of children's activities, and thus snacks are hoped to contribute the nutritional needs of child development and nurture. ${ }^{13}$

Supervision of the quality of student snacks should be done by the three responsible elements, the government, in this case, BPOM; the producers, in this case, the student snack traders; and the consumers, school-aged children. Supervision nowadays is not effectively conducted by these elements, so the producers often cheat, either intentionally or not. This puts students in a very disadvantaged situation. Thus, there is a need to establish supervision of student snacks of harmful additive ingredients like formalin, sodium tetra borate, and Rhodamine B.

\section{Sample Acquisition}

\section{EXPERIMENTAL}

Sample acquisition method was conducted by purposive sampling, which the samples were determined in consideration of the samples can represent the population. ${ }^{14}$ Representative samples were obtained from student snacks traders from 24 schools at Lubuk Pakam. Sample acquisition of students' snacks was conducted on September $7^{\text {th }}$ and $8^{\text {th }} 2015$. A total of 24 snack samples were obtained for formalin and sodium tetra borate examination, while 18 were obtained for Rhodamine B 2012 examination. The kind of snacks that were likely to contain formalin and sodium tetra borate were roasted meatballs, fried meatballs, fried tofu, and meatball skewers, while the kind of snacks that were likely to contain Rhodamine B were chili sauce, tomato sauce, red-colored candied fruit, red-colored ice, and chili chips.

\section{Research Location and Time}

The chemical analyses of the samples were conducted at Chemistry Laboratory, Department of Nutrition Lubuk Pakam on September $7^{\text {th }}-10^{\text {th }}$ 2015. Qualitative analysis was undertaken using a test kit by two repetitions (Diplo). The procedures used for analysis of the adulterants are listed below.

\section{Formalin Analysis Procedure}

The formalin analysis was as follows:

(1) The material/sample was ground by mortar, and 10 grams of the sample was obtained with a spatula, and poured into a test tube,

(2) A total of $20 \mathrm{ml}$ of boiling water was added, the suspension stirred, and let it cool,

(3) To the test tube, 1 drop of reagent $A$ and 4 drops of reagent $B$ were added,

(4) Then the contents of the tube were stirred with a spatula and incubated for 5-10 minutes for a color change to purple was a positive indication the sample contained formalin.

\section{Sodium Tetra Borate Analysis Procedure}

The sodium tetra borate qualitative analysis was also conducted using a test kit as follows:

1. The material/sample was ground by mortar, and 10 grams of the sample was obtained with a spatula, and poured into a test tube,

2. A total of $10 \mathrm{ml}$ of liquid reagent and $5 \mathrm{ml}$ of boiling water were added then stirred for 1 minute,

3. Put yellow paper into the tube and removed, 
RASĀYAN J. Chem.

Vol. 10 | No. 4 |1505-1510| October - December

4. When the paper dried, if the paper color changed to red, then the tested material positively contained sodium tetra borate .

\section{Rhodamin-B Analysis \\ Procedure}

The Rhodamine B qualitative analysis was conducted using the test kit as follows:

1. The material/sample was ground by mortar, and 10 grams of the sample was obtained with a spatula, and poured into a beaker glass,

2. A total of $20 \mathrm{ml}$ of boiling water was added then stirred and let cool,

3. Add 1 drop of reagent A and 4 drops of reagent B into the beaker glass and stirred for 1 minute,

4. A total of $5 \mathrm{ml}$ of the material to be tested was placed into another beaker glass that already has reagent, briefly stirred, incubated for 10-20 minutes; if the solution turned a purple color, then the tested material positively contained Rhodamine B.

There are 24 schools that have been chosen as well as samples. The brief information of location is described those are:

i. $\quad$ Lubuk Pakam's Pekan (3 Schools, Primary School (Government belonging: 3)

ii. BakaranBatu, (3 Schools: Government: 2 and Private: 1)

iii. Kampung Syahmat (3 Schools, all is Government) (Table-1).

\section{Type of Research}

The study involved qualitative research, i.e., the examination of student snack samples from Lubuk Pakam to see if they contained formalin, sodium tetraborate, or Rhodamine B contaminants.

\section{Tools}

Tools used in this research were test tubes, Bunsen burner, spatula, mortar, beaker glass, formalin, sodium tetra borate, and Rhodamine B test kits (made by ET Group Tegal Indonesia). The principle of this kit is the color of kit will be changing if the food contains Rhodamine B, the solution turned a purple color, then, and the tested material positively contained Rhodamine B. The limitation of this kit is only for qualitative test, so there is no exactly the limit detection.

\section{Material}

Materials used in this research were roasted meatball, fried meatball, sausage, stir-fried noodle, meatball skewer, fried tofu, chili sauce, tomato sauce, red-colored candied fruit, red-colored ice, and chili chips.

\section{Harmful/Contaminant Substances Examination}

\section{RESULTS AND DISCUSSION}

From the snacks samples suspected to contain formalin (24 samples), the percentage of materials positively containing formaldehyde was $25 \%$ (6 samples); such snacks were roasted meatballs, fried meatballs, meatball skewers, sausage, and stir-fried noodles. It means that $25 \%$ of the snacks are contaminated by formalin and unsafe to consume. It is parallel with the research by Andarwulan that showed $16 \%$ of the tested samples positively contain formalin. ${ }^{10}$

Meanwhile, in the snack samples suspected to contain sodium tetra borate ( 24 samples), the percentage of samples positively containing sodium tetra borate was $25 \%$ (6 samples) with the kinds of snacks being roasted meatballs, fried meatballs, meatball skewers, and fried tofu. It means that $25 \%$ of the snacks were contaminated by sodium tetra borate and unsafe to consume. It is parallel to the Meilala's research, which showed that $50 \%$ of the rice cakes contain sodium tetra borate in Medan. ${ }^{11}$

In the snacks suspected to contain Rhodamine B (18 samples), the percentage of samples positively containing Rhodamine B was $38.88 \%$ (7 samples), with the kind of snacks being chili sauce, tomato sauce, chili chips, candied fruit, and ice. This means that $38.88 \%$ of the snacks were contaminated by Rhodamine B and unsafe to consume. This is parallel with the research conducted by Gresshma that shows 
RASĀYAN J. Chem.

Vol. 10 | No. 4 |1505-1510| October - December

there are Rhodamine B at the street snacks especially in Pune region. ${ }^{13,15}$

Table-1

\begin{tabular}{|c|c|c|c|c|c|}
\hline S. No. & Name & Location & Belongs to & $\begin{array}{c}\text { Amount } \\
\text { of Snack } \\
\text { Seller } \\
\end{array}$ & $\begin{array}{c}\text { Amount } \\
\text { Variation } \\
\text { of Snack }\end{array}$ \\
\hline 1 & $\begin{array}{l}\text { Muhammadiyah Primary } \\
\text { School }\end{array}$ & LubukPakam 3 & Private & 3 & 5 \\
\hline 2 & $\begin{array}{l}\text { Government } 108384 \\
\text { Primary School }\end{array}$ & $\begin{array}{l}\text { LubukPakamPekan, Jl. } \\
\text { Diponegoro }\end{array}$ & Government & 5 & 9 \\
\hline 3 & $\begin{array}{l}\text { Government } 106381 \\
\text { Primary School }\end{array}$ & BakaranBatu & Government & 3 & 6 \\
\hline 4 & $\begin{array}{l}\text { Government } 104444 \\
\text { Primary School }\end{array}$ & Jati Sari & Government & 2 & 4 \\
\hline 5 & $\begin{array}{l}\text { Government } 107422 \\
\text { Primary School }\end{array}$ & PagarJati & Government & 3 & 6 \\
\hline 6 & $\begin{array}{l}\text { Government } 104241 \\
\text { Primary School }\end{array}$ & KampungSyamad & Government & 2 & 4 \\
\hline 7 & Katholik Primary School & $\begin{array}{l}\text { Jl. PematangSiantar, } \\
\text { PagarJati }\end{array}$ & Private & 4 & 8 \\
\hline 8 & $\begin{array}{l}\text { Government } 101902 \\
\text { Primary School }\end{array}$ & Sekip & Government & 3 & 6 \\
\hline 9 & $\begin{array}{l}\text { Government } 101898 \\
\text { Primary School }\end{array}$ & LubukPakamPekan & Government & 3 & 7 \\
\hline 10 & $\begin{array}{l}\text { Government } 101900 \\
\text { Primary School }\end{array}$ & LubukPakamPekan & Government & 3 & 6 \\
\hline 11 & $\begin{array}{l}\text { Government } 104242 \\
\text { Primary School }\end{array}$ & Jl. Impres & Government & 3 & 7 \\
\hline 12 & Tri Sakti Primary School & $\begin{array}{l}\text { Jl. PematangSiantar, } \\
\text { PagarJati }\end{array}$ & Private & 3 & 7 \\
\hline 13 & $\begin{array}{l}\text { Government } 101901 \\
\text { Primary School }\end{array}$ & LubukPakam & Government & 2 & 5 \\
\hline 14 & $\begin{array}{l}\text { Government } 105356 \\
\text { Primary School }\end{array}$ & LubukPakam 3 & Government & 2 & 4 \\
\hline 15 & $\begin{array}{l}\text { Government } 101899 \\
\text { Primary School }\end{array}$ & LubukPakam 3 & Government & 3 & 6 \\
\hline 16 & $\begin{array}{l}\text { Government } 107982 \\
\text { Primary School }\end{array}$ & LubukPakam 3 & Government & 4 & 8 \\
\hline 17 & $\begin{array}{l}\text { Government } 107955 \\
\text { Primary School }\end{array}$ & LubukPakam 3 & Government & 3 & 6 \\
\hline 18 & $\begin{array}{l}\text { Government } 106184 \\
\text { Primary School }\end{array}$ & Sekip & Government & 3 & 6 \\
\hline 19 & $\begin{array}{l}\text { Government } 106832 \\
\text { Primary School }\end{array}$ & Sekip & Government & 3 & 6 \\
\hline 20 & $\begin{array}{l}\text { Government } 105349 \\
\text { Primary School }\end{array}$ & PaluhKemiri & Government & 3 & 7 \\
\hline 21 & $\begin{array}{l}\text { Government } 105358 \\
\text { Primary School }\end{array}$ & Sekip & Government & 2 & 5 \\
\hline 22 & $\begin{array}{l}\text { Government } 101903 \\
\text { Primary School }\end{array}$ & BakaranBatu & Government & 3 & 6 \\
\hline 23 & $\begin{array}{l}\text { Government } 101927 \\
\text { Primary School }\end{array}$ & LubukPakam & Government & 3 & 6 \\
\hline 24 & $\begin{array}{l}\text { Government } 106831 \\
\text { Primary School }\end{array}$ & Bakaran Batu & Government & 2 & 5 \\
\hline
\end{tabular}


Those snack contaminants are spread in 54.2\% (13 schools) of primary schools in Lubuk Pakam region, thus meaning that $54.2 \%$ of Lubuk Pakam region have been contaminated by unsafe snacks to consume by school-aged children. The results of the formaldehyde testing of the snack samples are presented in Table2.

Table-2: Snacks with Formaldehyde, Sodium Tetra Borate and Rhodamine B Contaminant

\begin{tabular}{c|c|c|c|c|c|c}
\hline Contamination & \multicolumn{2}{|c|}{ Formaldehyde } & \multicolumn{2}{c|}{ Sodium Tetra borate } & \multicolumn{2}{c}{ Rhodamine B } \\
\hline & $\mathrm{n}$ & $\%$ & $\mathrm{n}$ & $\%$ & $\mathrm{n}$ & $\%$ \\
\hline Contaminated & 6 & 25 & 6 & 25 & 7 & 38,88 \\
\hline Non contaminated & 18 & 75 & 18 & 75 & 11 & 61.12 \\
\hline Amount & 24 & 100 & 24 & 100 & 18 & 100 \\
\hline
\end{tabular}

The result of the table can be indicated in the diagram as follow as:

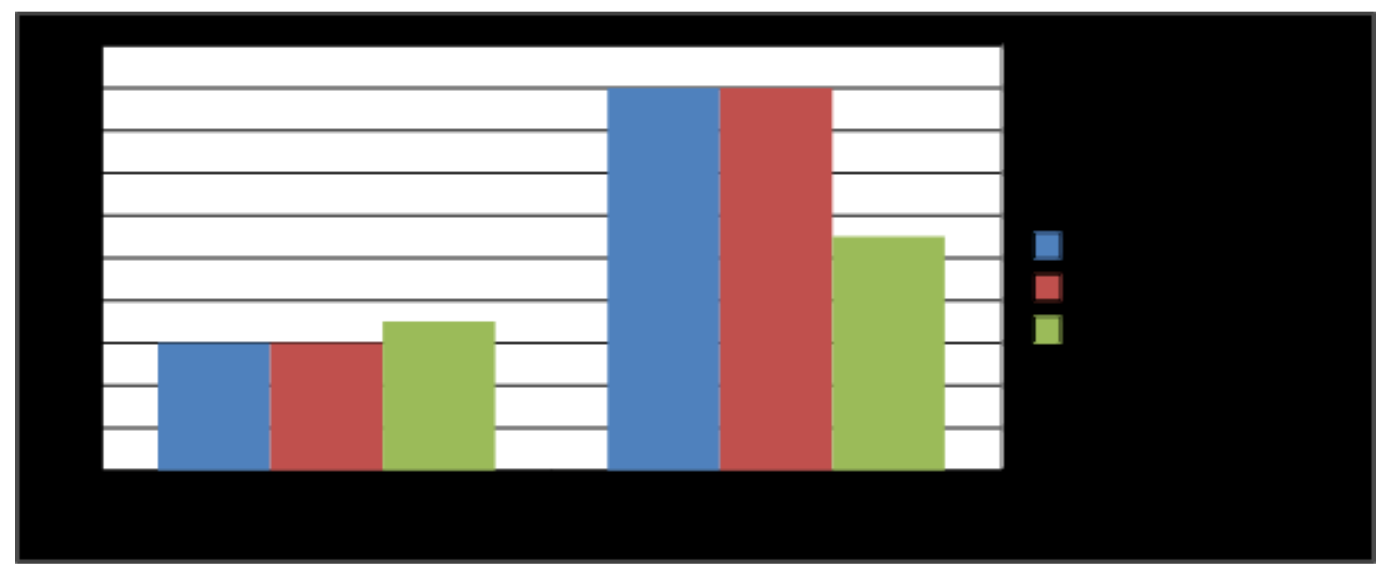

Fig.-1: Diagram contaminants and Non-Contaminated of Snack

From this diagram, it can be concluded that Rhodamine B is a higher contaminant $(38,88 \%)$ than Formaldehyde $(25 \%)$ and Sodium Tetra Borax $(25 \%)$ of snack samples, in school ,LubukPakam . From the 24 analyzed snack samples, 25\% (6 samples), were contaminated with formalin and were in school locations as follows: SD Muhammadiyah, SD N 108384 Jl. Diponegoro, SD N 104241 Syahmad, SD N 106381 BakaranBatu, SD N 104444 Jati Sari, SD N 107422 Pagar Jati. These locations had snacks such as: roasted meatballs, fried meatballs, meatball skewers, sausage, and stir-fried noodles. Meanwhile, from the 24 analyzed snack samples, $24 \%$ (6 samples) positively containing sodium tetra borate were in the school locations as follows: SD Muhammadiyah, SD N 108384 Jl. Diponegoro, SD N 101902 Sekip, SD N 104257, SD N 101900, SD N101927. These locations had snacks like roasted meatballs, fried meatballs, and meatball skewers. From 18 snacks potentially containing Rhodamine B analyzed, 38.88\% (7 samples) were found to actually contain Rhodamine B, with the school locations as follows: SD Muhammadiyah, SD N 108384 Jl. Diponegoro, SD N 101902, SD N 104257, SD N 101899, SD N 107982. These locations had snacks like chili sauce, tomato sauce, chili chips, candied fruit, and ice. Harmful ingredients (formalin, sodium tetraborate, and Rhodamine B) in the snacks in the school environment were found in $54.2 \%$ (13 schools) in Lubuk Pakam. It is parallel with the Andarwulan's research, who found that 16\% of snacks contain formalin, $9.1 \%$ of them contain sodium tetraborate, and $2.2 \%$ of snacks contain Rhodamine B, as conducted in 18 provinces in Indonesia. ${ }^{10}$

This shows that students' snacks sold at the schools in Lubuk Pakam have a quite high incidence of contaminants. Thus, the several foods containing formalin, sodium tetra borate, and Rhodamine B seller 
RASĀYAN J. Chem.

Vol. 10 | No. 4 |1505-1510| October - December

must be warranted serious attention for these and related agencies.

\section{CONCLUSION}

From this research, it is obtained the percentage of snacks positively containing formalin were $25 \%$ ( 6 of 24 samples), while those positively containing sodium tetra borate were $25 \%$ (6 of 24 samples), and positively containing Rhodamine B was $38.88 \%$ (7 of 18 samples).

\section{ACKNOWLEDGEMENT}

The writer would like to express his sincere thanks to Prof. Dr. Jansen Silalahi, M. App,Sc. Apt, as the first dissertation supervisor, for his valuable suggestions and guidance during the course of this work, and to Dr. Ir. Zulhaida Lubis. MKes under his help in estimation of this writing and valuable discussion. His Thanks are also due to Prof. Heru Santosa of the Faculty of Public Health, University of Sumatera Utara, Indonesia.

\section{REFERENCES}

1. Surveillance and Counseling Food Safety, (in Bahasa Indonesia), Balai Pengawasan Obat dan Makanan Republik Indonesia, ( 2011).

2. Y. Nurheti, Whact Out for Hazards Behind Delicious Food, Yogyakarta: Andi, p 35-38 (2007).

3. L.R. Tatukude, L. Loho, P.M. Lintong, Jurnal e-Biomedik (eBM), 2, 3 (2014).

4. R.Mayori, Jurnal Biologi Universitas Andalas, 2, 1, (2013).

5. K.Shimizu, M.Sugita, R.Yokote, H.Sekii, Y.Miyake, K.Kiyota, Chudoku Kenkyu, 16,447(2003).

6. M.J. Sarnak, J.Long, A.J. King, Clinical Nephrology ,51,122(1999).

7. J.Hansen, J.H. Olsen, Cancer Causes Control, 6,354(1995).

8. Z.Hojati, F.Dehghanian, Journal of Food Biosciences and Technology, 4, 2, (2014).

9. S. Palaniswany, O.N Balasundaram, Rasayan J. Chem., 2, 1 (2009).

10. Monitoring dan Profile Verification Student Snack Safety (in Babahasa Indonesia) Center IPB dan Direktorat Surveilan dan Penyuluhan, R.I. ( 2009).

11. M.Pongsavee, Journal Of Occupational Medicine and Toxicology, BioMed Central, 4, 27 (2009).

12. I.Maliala, J.Silalahi, L.Panjaitan, Jurnal Biologi Sumatra, 2, 1, (2008).

13. J.Silalahi, F.Rahman, Jin Ma, 1, 2 (2011).

14. Hamida, Khairuna, S. Zulaekah, and Mutalazimah, Jurnal Kesehatan Masyarakat, Surabaya, 1, 1 (2012).

15. Sudjana, Statistical Method, p 42 (2005).

16. R.L. Gresshma and M.P.R.Paul, Malaysian Journal of Forensic Sciences, 3, 1 (2012).

17. P.Dasgupta, N.Naskar and S.Maji, Rasayan J Chem, 4, 3 (2011).

18. M.Thenmozhi, M.Karpagavalli and R.K Seenivasan, Rasayan J. Chem., 9, 4 (2016).

19. A.M, Surjushe and A.B.Patil, Rasayan J. Chem.,8, 3 (2015).

[RJC-1795/2017] 